\title{
Indicators for Sustainable Development Strategies and Components of Tourism Regions in Egypt A Study of Alexandria and the Northwest Coast
}

\author{
Waleed Hussein Ali \\ Fayoum University, Faculty of Engineering, Department of Architecture, Fayoum, Egypt
}

Email address:

Waleed.a.hussien@gmail.com

To cite this article:

Waleed Hussein Ali. Indicators for Sustainable Development Strategies and Components of Tourism Regions in Egypt A Study of Alexandria and the Northwest Coast. International Journal of Environmental Protection and Policy. Vol. 3, No. 2, 2015, pp. 39-52.

doi: 10.11648/j.ijepp.20150302.13

\begin{abstract}
Sustainable urban development for tourism has been a priority for Arab and European institutions since the mid 1990's. In recent years, the tourism industry has grown in importance because of its positive effect on overall (economic, social, cultural, political and psychological) development ${ }^{1}$. Many economists, sociologists, anthropologists, psychologists, geography and administration experts are showing increased interest in the various services-related activities undertaken in different fields of tourism, and in tourism's relation to sustainable development; issues that have also become the subject of social and economic demand. The social demand is a reflection of the human desire to move and travel, while the economic aspect concerns the employment opportunities available for young people of both sexes in the various fields of tourism, which can gradually contribute to the resolution of the unemployment problem. Moreover, tourism plays a significant part in accelerating the extension of urbanization by planning cities and tourist resorts, constructing and developing roads and utility networks, investing available economic resources and by optimizing the use of environmental or local resources to manufacture popular products. Since it helps to increase foreign currency inflows from abroad, tourism is also an important source of national income for tourist-attracting countries.
\end{abstract}

Keywords: Tourism Development, Tourism Region, North Coast Region, Development Indicators, Sustainable Development

\section{Research Objective}

This study aims to explain the relationship between crucial sustainable development and the development of tourism regions in Egypt. It reviews sustainable development strategy indicators for the Northwest Coast and Alexandria regions and attempts to identify their positive and negative features.

\section{Research Methodology}

An inductive approach is used to study the available data and information on planning and tourism regions in Egypt. Following analysis of this data, indicators for the sustainable development of the Northwest Coast and Alexandria regions (selected because of their great importance to the

1 Mohamed Youssry Ibrahim De3bbes - Sena3et al seya7a bayn al nazareya wa al tatbeeq - First Edition, 2003. development process in Egypt) are identified.

\section{Targeted Regional Development 2}

The integrated development of economic, social, cultural, urban and environmental sectors in a specific region within the framework of a comprehensive national plan that defines development strategy, identifies general development indicators, and defines the size of investments in the development process.

Tourism Development: is a component of regional development (it is one aspect of the economic development of a region).

As a driving force behind a successful process of

2 Mohsen Abdel Sa7eb Al Mozafar (previous reference) 
sustainable tourism development, regional development leads to environmental, social and cultural sustainability that reduces disparities or gaps in existing community systems and allows for continued development while safeguarding the right of future generations to community resources.

Tourism Development: Objectives and Relation to Regional Development

Table 1. Tourism Development: Objectives and Relation to Regional Development

Tourism Development Objectives
Securing the continuous and balanced growth of State revenues from
tourism Contributing to the development and conservation of the
environment
Strengthening links between production in the tourism industry and
production in other sectors

Raising the employment rate by creating new employment opportunities in the tourism industry and related sectors

Upgrading and developing community services in all fields (education, health, social, recreational and cultural) through the establishment of colleges and institutes specialized in hotel management, tourism guidance and the management of public enterprises

Underscoring the positive social and cultural impact of tourism

Ensuring that tourism sector plans contribute to local and urban development by developing new tourist attraction areas in the isolated or marginalized areas of different localities and linking these to developed regions (integration of uninhabited spaces into the developed regions)

Working on formulating tourism development strategies that are consistent with national interests

\section{Regional Development Objectives}

Maximizing possibilities for exploiting untapped resources

Inventory and evaluation of various resources and economic opportunities with a view to promoting economic integration and applying the concept of sustainable development

Realizing social justice and focusing on the human factor by promoting education and scientific research (which are both the goals of development and one of its primary resources)

Creating regional equilibrium by eliminating economic, social and cultural disparities among different regions of the State

implementing the spatial dimension and population settlement objectives of the national and regional development strategy

Source: Heba Mostapha Hassan Mohamed, Taqyeem dor khettat al tanmeya al seya 7 eya fi 3amaleyat al tanmeya al eqleemeya fi misr, Unpublished MA thesis, Faculty of Urban and Regional Planning, Cairo University, 2012

Sustainable Tourism: focuses on the point of encounter between the needs of tourists and those of the host region, thus protecting and enhancing future development opportunities. The management of all resources is geared towards fulfilling economic, social and spiritual needs, while simultaneously preserving the existing culture, environment, necessary biodiversity conditions, as well as all life systems and necessities.

\subsection{The Concept of Eco-Tourism and Sustainability3}

Eco-tourism is an educational, learning and cultural process that aims at acquainting tourists with the distinctive features and attributes of an environment and facilitating their integration within that environment. Sustainable tourism refers to the optimal exploitation of tourist sites by ensuring that the number of visitors corresponds to the nature of the site and those tourists are aware of the location's significance and of the suitable behavior to adopt, thereby preventing damage to both the site and the tourists. Sustainable tourism satisfies the needs of tourists while protecting tourist sites and creating additional employment opportunities for the local community. It strives to manage all available resources (economic, social, natural and esthetic) in accordance with the location's culture and heritage, and recognizes the need to maintain ecological balance and proper biodiversity

3 Dr, Fahd Abdel Karim Ali Torkistani, Al seya7a al bee'eya, mafhoomha wa 3anaserha, 2008 conditions. The World Tourism Organization (WTO) focused on the concept of sustainable tourism in its 1980 Manila Declaration, at its 1982 meeting in Acapulco, Mexico, at its 1985 General Assembly meeting in Sofia, and in Cairo in 1995.

\subsection{The Principles of Sustainable Tourism4}

We may conclude that the principles of sustainable tourism are the following: Tourism planning, development and management must constitute a component of the overall sustainable development strategies for any given region or country. To provide optimal benefits, tourism planning and management should be undertaken in an integrated, unified manner that ensures the involvement of different government agencies, private foundations and citizens (groups and individuals).

These agencies, foundations, groups and individuals should adhere to certain ethical and other principles, such as respect for the host region's culture, environment and economy and for its traditional lifestyle and manners (including its political configuration). Tourism planning and management should focus on sustainability and aim to protect the host region by making optimal economic use of

4 Tasyeer aleyat ta7qeeq al seya 7 a al mostadama ma 3 altatbeeq 3 ala alwa7at al dakhla wa al kharga be misr, First International Symposium (Urbanism and Sustainable Tourism), Institute of Urban Management Techniques, University of M'sila, Algiers, 7 / 8 December, 2011 
its natural and human environment.

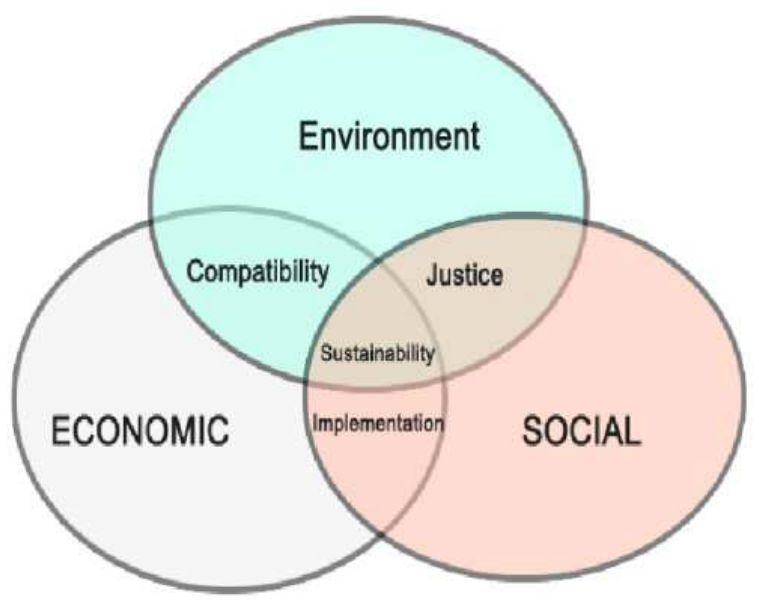

Figure 1. Dr, Fahd Abdel Karim Ali Torkistani, Al seya7a al bee'eya mafhoomha wa 3anaserha, 2008

Special care should be taken to ensure that profits from tourism are equitably distributed among tourism promoters, members of the host community and the host region.

Studies and information on the nature of tourism and its impact on local inhabitants and on the cultural environment should be available prior to, and during, the development process. In particular, this information should be accessible to members of the local community, enabling them to participate in, and influence, overall development trends.

Prior to embarking on a tourism development process, or on any other project, it is crucial to complete an integrated analysis of environmental, social and economic plans that takes into account local environment and community requirements. 5

An inspection, control and rectification program should be in place during all phases of tourism development and management, enabling local inhabitants and others to benefit from available opportunities and to adapt to future changes that will affect their lives.

\subsection{The Concept of Eco-Tourism and Sustainability}

Refers to an educational, learning and cultural process that concerns a given environment's components; it is a means for acquainting tourists with the host environment, and how best to adjust to it. Sustainable tourism refers to the optimal exploitation of tourist sites by ensuring that the number of tourists entering a site corresponds to its nature and that visitors are aware of the location's significance and of how to behave in a responsible and knowledgeable manner, thereby preventing damage to either party. 6

5 Tasyeer aleyat ta7qeeq al seya7a al mostadama ma3 altatbeeq 3 ala alwa7at al dakhla wa al kharga be misr, First International Symposium (Urbanism and Sustainable Tourism), Institute of Urban Management Techniques, University of M'sila, Algiers, 7 / 8 December,

6 Tasyeer aleyat ta7qeeq al seya $7 a$ al mostadama ma3 altatbeeq 3 ala alwa 7 at al dakhla wa al kharga be misr, First International Symposium (Urbanism and Sustainable Tourism), Institute of Urban Management Techniques, University of M'sila, Algiers, 7 / 8 December, 2011

\subsection{Traditional Tourism Development and Sustainable Tourism Development}

A comparison between traditional and sustainable tourism development is presented in the table below.

Table 2. Traditional Tourism Development and Sustainable Tourism Development

\begin{tabular}{|c|c|c|}
\hline & $\begin{array}{l}\text { Traditional Tourism } \\
\text { Development }\end{array}$ & $\begin{array}{l}\text { Sustainable Tourism } \\
\text { Development }\end{array}$ \\
\hline Concept & Rapid development & Development in stages \\
\hline Limitations & No limitations & $\begin{array}{l}\text { Has certain limitations } \\
\text { and a defined } \\
\text { absorptive capacity }\end{array}$ \\
\hline Time Span & Short-term & Long-term \\
\hline Type & Quantitative tourism & Qualitative tourism \\
\hline $\begin{array}{l}\text { Management of } \\
\text { Development } \\
\text { Processes }\end{array}$ & External & $\begin{array}{l}\text { Through local } \\
\text { inhabitants }\end{array}$ \\
\hline $\begin{array}{l}\text { Development } \\
\text { Strategies }\end{array}$ & $\begin{array}{l}\text { Unplanned } \\
\text { development }\end{array}$ & $\begin{array}{l}\text { Planning precedes } \\
\text { development }\end{array}$ \\
\hline Planning & $\begin{array}{l}\text { Partial planning of } \\
\text { unconnected, isolated } \\
\text { sectors }\end{array}$ & $\begin{array}{l}\text { Comprehensive, } \\
\text { integrated planning }\end{array}$ \\
\hline $\begin{array}{l}\text { Construction } \\
\text { Methods }\end{array}$ & $\begin{array}{l}\text { Focus is on building } \\
\text { vacation units }\end{array}$ & $\begin{array}{l}\text { Construction allows for } \\
\text { environmental } \\
\text { conditions \& land use } \\
\text { plans }\end{array}$ \\
\hline Architectural Style & $\begin{array}{l}\text { Traditional urban } \\
\text { buildings }\end{array}$ & $\begin{array}{l}\text { Local architectural } \\
\text { styles }\end{array}$ \\
\hline Adopted Programs & $\begin{array}{l}\text { Project planning } \\
\text { programs }\end{array}$ & $\begin{array}{l}\text { Planning programs are } \\
\text { based on the } \\
\text { sustainability concept }\end{array}$ \\
\hline Tourist Attributes & $\begin{array}{l}\text { Tourist groups, large } \\
\text { numbers }\end{array}$ & $\begin{array}{l}\text { Individuals and small } \\
\text { tourist groups }\end{array}$ \\
\hline Duration of Stay & Short stays & Long stays \\
\hline Demeanor & $\begin{array}{l}\text { Noise and annoying } \\
\text { sounds }\end{array}$ & $\begin{array}{l}\text { Sensible and calm } \\
\text { behavior }\end{array}$ \\
\hline Repeat Visits & $\begin{array}{l}\text { Single visit to the } \\
\text { location }\end{array}$ & $\begin{array}{l}\text { Probability of repeat } \\
\text { visits to the location }\end{array}$ \\
\hline Class of Tourist & $\begin{array}{l}\text { Different educational } \\
\text { levels }\end{array}$ & $\begin{array}{l}\text { Highly educated and } \\
\text { cultivated }\end{array}$ \\
\hline
\end{tabular}

Source: Atta Allah Farouq (2003), p. 63

Sustainable tourism meets the needs of tourists while also protecting and preserving tourism regions and creating employment opportunities for local communities. It strives to manage all available resources (economic, social, natural and esthetic) in keeping with the location's culture and heritage, and recognizes the need to maintain ecological balance and proper biodiversity conditions. ${ }^{7}$

\subsection{Tourism Region Definition}

According to Al Roubi (1987), a tourist region8 is an area (or a plot of land) that contains key attraction elements drawing tourists to visit it and stay in it for a specific period, and to take part in various tourist activities. It can be either a final destination, or a stopover point on the way to another destination. This explains the importance of interconnecting

7 General Authority for Urban Planning, Estrategiat al tanmeya le mo7afazat al gomhoreya, Iqleem al eskandereya, Chapter 3, 2008

8 Nabil Al Roubi, Al Takhteet al seya 7i, Cairo, pp. 159, 160 
tourist resources and visit durations, according to the purpose of the trip and the tourists' preferences.

\section{Planning for Tourism Development}

Successful tourism development requires planning in accordance with a clearly defined national tourism development policy that is based on scientific approach. This is because tourism is a multifaceted activity linked to many other sectors of the development process. A scientific approach to tourism development planning realizes the following9:

1. Coordination and harmonization between the tourism sector and other sectors within the overall development system, due to the complex interconnection and mutually dependent relations among the different sectors (cultural, economic, environmental ...).

2. Creating a balance, within the tourism sector itself, among sometimes-conflicting needs that in most cases have to compete over limited resources

3. Adopting clearly defined, integrated approaches that benefit all the participants in tourism development during the various planning and implementation phases that expands the base of participants and ensures effective interaction in order to realize plan objectives

4. Laying the foundation for legislature that promotes and ensures successful tourism development

\subsection{Tourism Planning Definition}

Tourism planning is the process of drafting a blueprint of the estimated future tourism activity in a given country over a specific period. Formulating tourism plan objectives and achieving rapid and regular tourism development necessitates inventorying the country's tourism resources as part of the preparation and implementation of a coherent development plan that covers all branches of tourism activity and all tourism regions in a country. 10

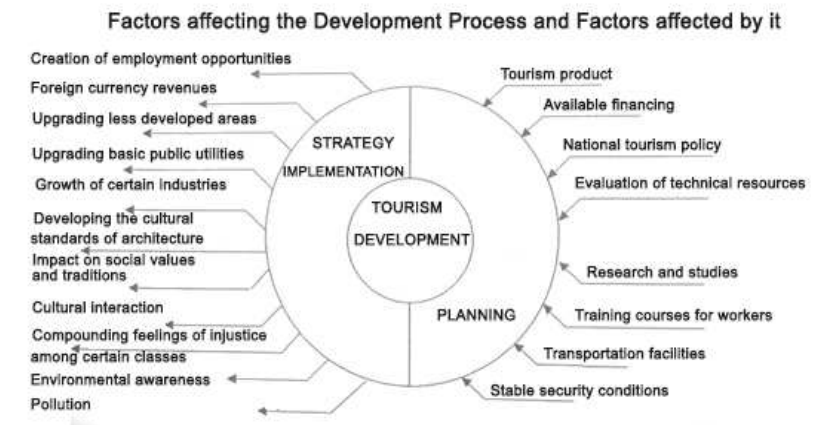

Figure 2. Nabil Al Roubi, Al Takhteet al seya7i, Cairo, pp. 159, 160

9 Ibrahim Bazazou, Takamol al eqleem al takhteeti wa al aqaleem al seya7eya, published article, menotourism.com

10 Fahd Abdel Karim Ali Torkistani, Al seya7a al bee'eya, mafhoomha wa 3anaserha, First Edition, 2008
Tourism planning should not be perceived to be solely the province of official government bodies; it should be a joint work program among government agencies, the private sector and individuals. From the formulation of desired objectives up to the application and implementation of the tourism plan, tourism planning must be a joint operation, undertaken by all organizers of the tourist sector; government agencies responsible for supervising the sector, tourist service providers (institutions and businessmen), the consumers of these services (tourists), and the host community11.

Successful tourism planning depends on a number of factors, including:

- Ensuring that the tourism plan is an integral part of a comprehensive national social and economic development plan

- Creating an equilibrium among the various economic sectors

- Tourism sector development should be considered one of the strategic options for economic development

- Including the tourism industry among the production sectors in the State's economic structure

- The State must define the level of growth and the size of tourist flow required

- Clearly defining the roles of the private and public sectors in the development process

- Focusing on the relation between tourism planning and economic activity as a whole, and on its connection to environmental preservation

- A number of tourist development pioneers view the following four relationships as necessary factors for successful tourism planning:

The relationship between planning and economic activity:

In any region, successful tourism activity is closely linked to the scale of economic activity capable of engendering a constant increase in income and to the local economy's ability to absorb and use this income. 12

The relationship between planning and the environment:

We believe that tourism and the environment are one and the same, because the tourist flow is directly associated with factors that attract tourists, such as climate, stunning natural landscapes, beaches etc, as well as with man-made tourist attractions (historical and archeological sites, modern tourist attractions, and others). This is why the preservation of environmental assets is so crucial.

The relationship between planning and tourist site visitors:

It is important to teach local residents to provide tourists with the information they need to enjoy their stay intellectually; the combination of psychological enjoyment and intellectual enrichment increases tourists' desire to re-

\footnotetext{
11 Majalet game3at teshreen lelderassat wa albo7outh al 3elmeya - selselat al 3oloom al'eqtessadeya wa al qanooneya, Vol. 28, Issue 3 (2006)

12 General Authority for Tourism Development website - www.tda.gov.eg Molakhass qera'at estratejeya al tanmeya le 'eqleem al eskandereya - mo7afazat matruh-al moqtara7aat wa al mortakezaat
} 
visit the region. 13

The relationship between planning and the influx of foreign currency:

Because the objective of planning is to increase the State's foreign currency resources, the success of tourism planning (especially in developing countries) is measured by its ability to increase foreign currency influx - whether through revenues from international tourism or through the investment of capital in tourism projects.

\subsection{Tourism Planning Significance and Objectives}

Tourism planning, a scientific approach to the organization and management of all tourist activity types and components, plays a primordial role in the development of tourist activity. It provides a common framework for decision-making in tourism resource management and identifies methods and trends to be adopted by the parties responsible, thus facilitating their work and preventing the waste of time and effort.

Tourism planning leads to coordinating and uniting the efforts expended by all parties responsible for the development of the tourism sector, reducing the duplication of decisions and actions and contributing to the successful achievement of general and specific objectives of tourism activity. Consequently, tourism planning is affected more by political, social and natural vacillations than it is by factors of production and other economic forces.

At the regional level, tourism planning is less specialized and detailed than it is at the local level, but much more so than at the national level - although the degree of specialization also depends on the size of the country and of the region. The national plan of a small country may be as detailed as the regional plan of a larger country (smaller countries may therefore not need separate regional and national plans).

\subsection{Tourism and Urban Development Approaches and Methods}

Tourism and urban planning and development approaches and methods differ from one country to another, and from one area to another, depending on the existing circumstances, the policies adopted and the components of individual tourist sites and tourism regions. Barbaza listed the following approaches to the development of tourism activity:

\subsubsection{Intensive and Planned Topical Development}

This approach was widely adopted in East European countries where local seaports controlled sea traffic on the Black Sea coast, in Varna and Burgas. To increase their foreign currency income during the post World War II era, the governments of these countries drafted programs aimed at the growth and promotion of tourism in various regions. Detailed market analyses and evaluations of the absorptive capacity of beaches were undertaken, and the necessary land

13 General Authority for Tourism Development, Estratejeya le tanmeyat al seya7a 7 atta 3 am 2017 plots were provided (a special system for managing development lands was established). To create partnerships between the private and public sectors, owner consortiums were set up, and the State provided adequate government funding. 14

\subsubsection{Comprehensive Development}

The comprehensive development experiment was applied in East European countries. It involves the development of both the existing centers and new functional groups, and linking these to highways and utility networks, leading to the unification and growth of the region. The process takes place within the framework of a balanced development of the local population and a region's available economic resources, and covers all regional components (physical, economic, social ...), while focusing on environmental preservation and sustainability. ${ }^{15}$

\subsubsection{Integrated Development}

In this approach, a single party (the State) is responsible for realizing an integrated, homogeneous development process conducted according to a clearly formulated development strategy, with well-defined policies. The reason is that the vast technical and financial resources necessary for this type of development are available to the State, but not to individual investors. Integrated development has been implemented in many countries and regions. It can take different forms, depending on development management methods, funding sources, or the population benefitting from development:

Balanced development: Based on the unified management of numerous projects

Management through a single agency that provides the required funding and employment opportunities, with local agencies assisting in certain areas (such as public utilities and other infrastructural works).

Rapid development: Through technical and financial cooperation between agencies and institutions.

Functional development: Through integrated urban planning, that turns the tourism region into a unified, integrated entity.

Motivational development: Independent parties (development companies) independently develop a given region based on previously laid and declared development plans. These companies play the part of polarized catalysts for development; they provide the momentum required for their development projects in keeping with their economic vision within the framework of a general regional and State plan, and according to conditions defined by the responsible agency, as follows:

- Independent (single-handed) development through a large company that supplies basic tourism facilities

14 Fatena Al Wattar, Al malame7 altakhteeteya le ta7qeeq afaaq al tanmeya al mostadama, Al mobadarat wa al 'ebda3 al tanmawi fi al madeena al 3 arabeya, Jordan, 2008

15 Mohamed Youssry Ibrahim De3bbes - Sena3et al seya 7 a bayn al nazareya wa al tatbeeq - First Edition, 2003 
- Initial success in providing tourism facilities and activities engenders confidence among investors and development agencies and attracts more investors, development agencies and tourists, which in turn increases tourist demand for the development of complementary and secondary facilities. This creates room for active participation and motivates different actors to participate in the development process.

- The absolute growth phase (according to the free market theory), which depends on the status and capabilities of operating conditions

In the author's view, the integrated development approach is the most suitable one for the development of tourist regions in developing countries. Integrated development takes into account tourism promotion and growth programs that aim to increase foreign currency revenues, provides the necessary funding, creates employment opportunities and engages the participation of local agencies. Moreover, this approach entails integrated urban planning aimed at transforming tourist regions into unified, integrated entities. ${ }^{16}$

\subsection{Standards and Methods for Identifying Tourism Development Components}

Determining spatial frameworks for the implementation of present and future tourist development plans has become one of the prerequisites of tourism development. A tourism region is the spatial framework within which tourism sector plans are implemented; it can be used to measure the spatial dimension of tourism sector plans. It is extremely important, during the initial stages of formulating a country's tourism plan, to define the concept of 'tourism region'. This definition will allow the identification of a region's potential human and natural resources and thus help to determine the basic requirements for implementing the desired tourism development. $^{17}$

\subsection{Factors Affecting the Demarcation of Tourism Regions}

Natural Components: Refers to the availability of natural and man-made tourist attraction elements. Natural tourist attraction elements include climate, topography, natural resources, mineral springs, mud baths, medicinal hot water springs, nature reserves etc. Man-made elements include historical sites and archeological monuments, cultural landmarks such as museums and art galleries, cultural and traditional events such as exhibitions, festivals etc. A region's natural components are used to measure the actual absorptive capacity of available resources in order to implement a balanced exploitation of resources that ensures their continuity (ongoing development), and to protect the distinctive characteristics of certain regions. The more varied the tourist attractions of a region, the more unique it becomes

16 General Authority for Urban Planning, Al mokatat al estratigi al qawmi lel tanmeya al 3omraneya wa manateq al hay'a al 3ama lel takhteet al 3omrani-Al itar al 'eqleemi letanmeya mo7afazat eqleem al eskanderiya

17 Central Agency for Public Mobilization and Statistics (CAPMAS), General Census for Population, Housing and Establishments, 2006, and 2008 Estimations as a tourist destination and the greater its influence on the regional development process. ${ }^{18}$

Urban Components: Refers to the availability of necessary infrastructural elements (potable water networks, sewage systems, all types of communication networks), transportation facilities (airports, seaports, railways, road networks ...), various types of tourist accommodation (number and class of rooms), in addition to indispensable complementary tourist services, such as restaurants, travel agencies, clubs and theatres.

Economic Components: Refers to the economics of the tourism sector and its importance in each region. This is reflected in the compatibility between available elements of tourism supply and demand, including factors that attract tourism investment, because capital is a crucial component in the establishment of facilities, hotels, travel agencies and centers, as well as the equipment, tools and buildings needed for these facilities.

Social Components: Refers to one of the most important factors affecting the success of tourism development; the traditions and values of the population involved in tourism, including personnel working in the tourism sector (in official agencies such as tourism departments and ministries and other sectors, as well as in other facilities working in the industry). This component underlines the importance of learning, training, educating and comprehending the nature of tourism and its requirements.

Administrative and Political Factors: The social and political attributes of regions and internal administrative borders should both be taken into account during the demarcation of tourism regions, not only to facilitate management and administration but also because tourism development plans are implemented within these administrative borders.

Future Dimensions of Regional Development: may modify the thinking on demarcation (State's stance towards tourism development, possible discovery of new tourism resources or trends, new tourist centers etc $)^{19}$

\section{Proposals for the Demarcation of Egyptian Tourism Regions}

Numerous attempts to divide Egypt into tourism regions have been made by specialists and others involved tourism. Below is a review of some of these demarcation proposals and the elements upon which they are based:

\subsection{Some Proposed Demarcations ${ }^{20}$}

Dr. Ahmed Al Essawy's Proposal (1987):

1. Marina Zone: The country's northern zone, it includes the Delta, Alexandria, Mersa Matruh and

18 Ahmed Fawzi, Madkhal ila 3elm al seya7a, Dar Al fekr al gamee3ee, 2008, pp. $159-160$

19 Majalet game3at teshreen lelderassat wa albo7outh al 3elmeya - selselat al 3oloom al'eqtessadeya wa al qanooneya, Vol. 28, Issue 3 (2006)

20 Magda Mohamed Gom3a, Goghrapheyat misr al seya7eya, 2000, p. 671 
extends southwards to Siwa and the Qattara Depression

2. Memphis Zone: The central zone, it includes Greater Cairo, Fayoum, Beni Suef, Minya and Bahariya, as well as the Sinai and the Suez Canal

3. Located south of the Memphis Zone, it extends southward to the borders of the Nubian Zone and stretches laterally from the Red Sea coast in the east to the Libyan border in the west. Aswan is its principal capital city. 21

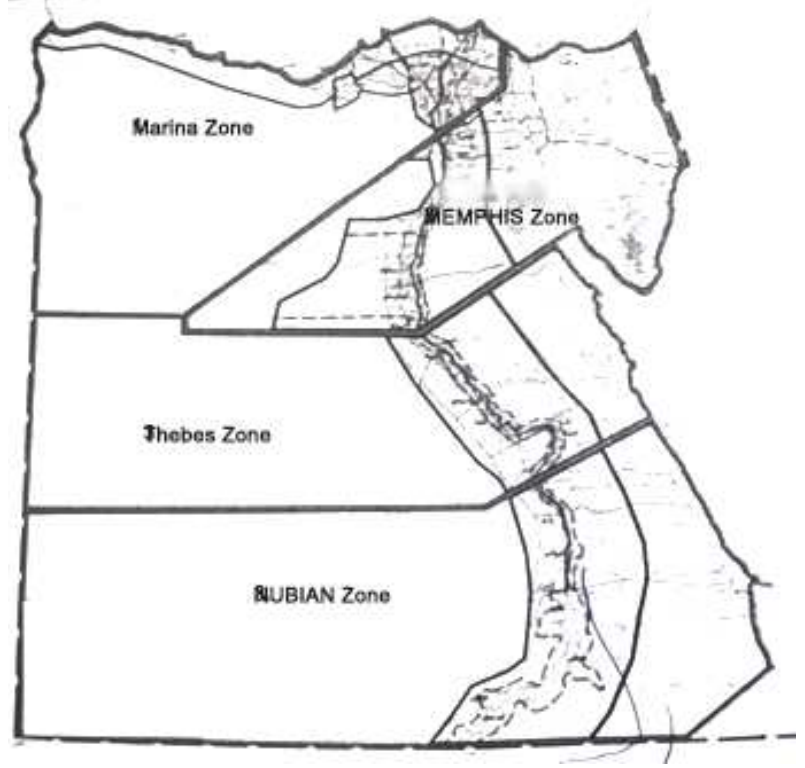

Figure 3. Dr. Ahmed Al Essawy's Tourism Region Demarcation Proposal

Source: Magda Mohamed Gom3a, Goghrapheyat misr al seya7eya, 2000, p. 671

It is to be noted that the proposed demarcation does not consider administrative borders, and that each region covers an extremely large area, making it difficult to build an integrated infrastructure. The proposal focuses on ensuring that each region has a waterfront (sea or Nile front). The demarcation disregards the element of natural homogeneity among regions and the similarities among individual regions' natural attributes (Kharga Oasis is split into two separate regions, for instance). The proposal does not take into account social aspects and the homogeneity of population characteristics, an essential component of tourism development. $^{22}$

\subsection{Egyptian Ministry of Tourism Proposal}

1. Cairo Region: Cairo, Giza, Fayoum and Beni Suef governorates

2. Alexandria Region: Alexandria Governorate, extending from Abu Qir in the East to Agami in the West

21 Magda Mohamed Gom3a, Goghrapheyat misr al seya7eya, 2000

22 Mohamed Youssry Ibrahim De3bbes - Sena3et al seya 7 a bayn al nazareya wa al tatbeeq - First Edition, 2003
3. Delta Region: Includes Egypt's northern governorates, from the shores of the Mediterranean and Lake Borolos in the north to the northern borders of south of Cairo

4. Upper Egypt Region: Minya, Assiut, Sohag, Qena and Aswan governorates to the Sudanese border in the south

5. Suez Canal Region: Port Said, Ismailia and Suez governorates

6. Northwest Coast Region: (Mediterranean Sea Region), includes Mersa Matruh

7. Oases Region: (Western Desert Region), includes Siwa, Bahareya, Farafra, Dakhla and Kharga Oases

8. Sinai Region: North Sinai and South Sinai governorates

9. Red Sea Region: Includes the Red Sea Governorate and extends from the south of Suez all the way to Egypt's southern border with the Sudan

The basis of this demarcation proposal is that (within a comprehensive tourism framework and according to the demand for different types of tourism and the use made of these), each region provides a unique type of tourism in line with its distinctive natural, demographic, economic and architectural characteristics.

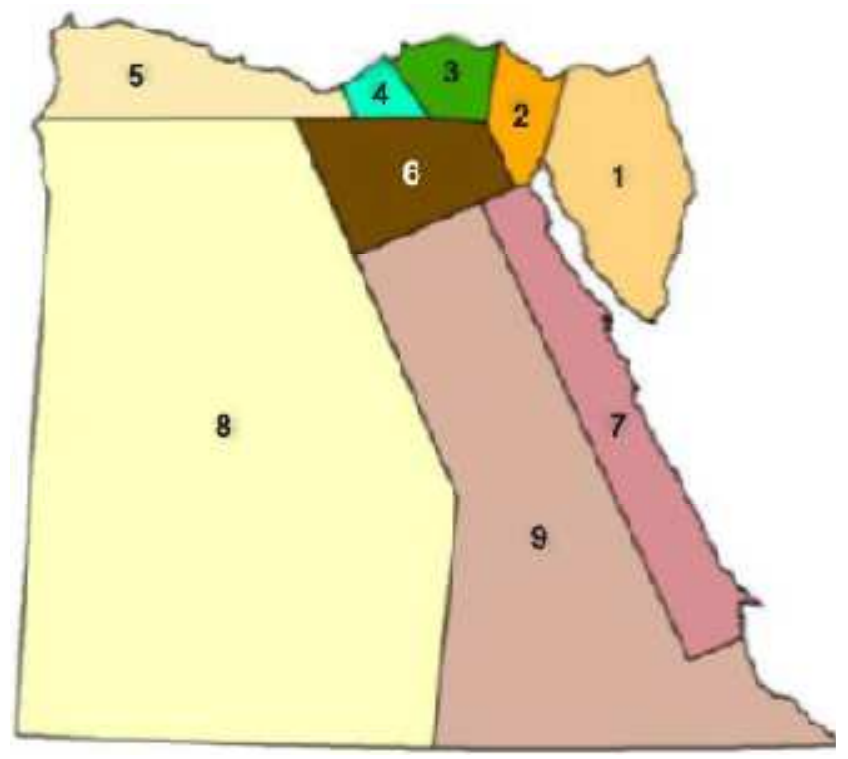

Figure 4. Egyptian Ministry of Tourism Region Demarcation Proposal

Source: Tourism Development Authority

It is to be noted that, in some of the regions, this proposal does not heed administrative borders. Also, no attention is paid, in some of the regions, to the diversification of tourism resources and natural resources. The proposal does not allow for linking the development of Red Sea Coast beach tourism to the development of cultural and archeological tourism in the Nile Valley. Moreover, the proposal overlooks the need of coastal regions, such as the Red Sea and Northwest Coast, for land buffer zones. Finally, the Oases Region does not include desert areas, and there is therefore no opportunity to exploit 
and develop safari tourism. ${ }^{23}$

\subsection{The Japan International Cooperation Agency (JICA) Proposal $^{24}$}

The demarcation of tourism regions in this proposal is based on a number of premises:

- Ensuring that the demarcation of regions is in keeping with national objectives and tourism development and planning goals

- Homogeneity of natural attributes and of tourism demand and supply factors

- Egypt is divided into five major tourism regions, which are subdivided into 13 tourism sub-regions, as follows:

1. Cairo Region: Cairo, Giza, Suez, Central Delta and Fayoum

2. Nile Valley Region: Divided into two sub-regions (Central Nile Valley and the Upper Nile Valley)

3. Red Sea Region: South Sinai Governorate and the Red Sea Governorate

4. Mediterranean Sea Region: The north coast from Rafah in the East to Al Salloum in the West; it is divided into three sub-regions (North Sinai, Alexandria and Mersa Matruh)

5. Oases Region: Includes all the Western Desert oases, and is divided into two sub-regions (Siwa and the Western Desert)

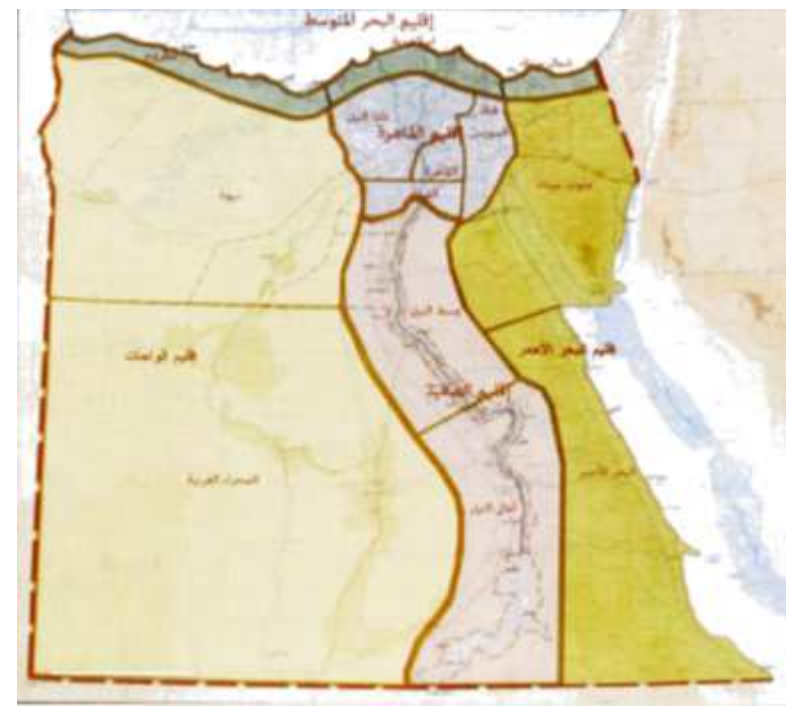

Figure 5. JICA Demarcation Proposal

Source: JICA study team - The study On Tourism Development Projects In Egypt

It is to be noted that this demarcation proposal only takes into account the homogeneity of natural attributes and

23 General Authority for Urban Planning, Ta7deeth estratejeyat al tanmeya al shamela lel sa7el alshemali algharbi wa zaheeroh al sa7rawi $(2010-2032)$, April 2011

24 JICA study team - The study On Tourism Development Projects In Egypt tourism economics; it overlooks the factors of population traits and urban characteristics and disregards administrative borders in some of the regions. 25

\subsection{Indicators for Measuring Tourism Development Components}

On the basis of the above review of factors affecting successful tourism development and some of the tourism region demarcation proposals that depend on the optimal exploitation of development components, we can identify indicators for measuring tourism development components by evaluating the considerations adopted by the demarcation process, as illustrated in the table below:

Indicators for Measuring Tourism Development Components

Table 3. Indicators for Measuring Tourism Development Components

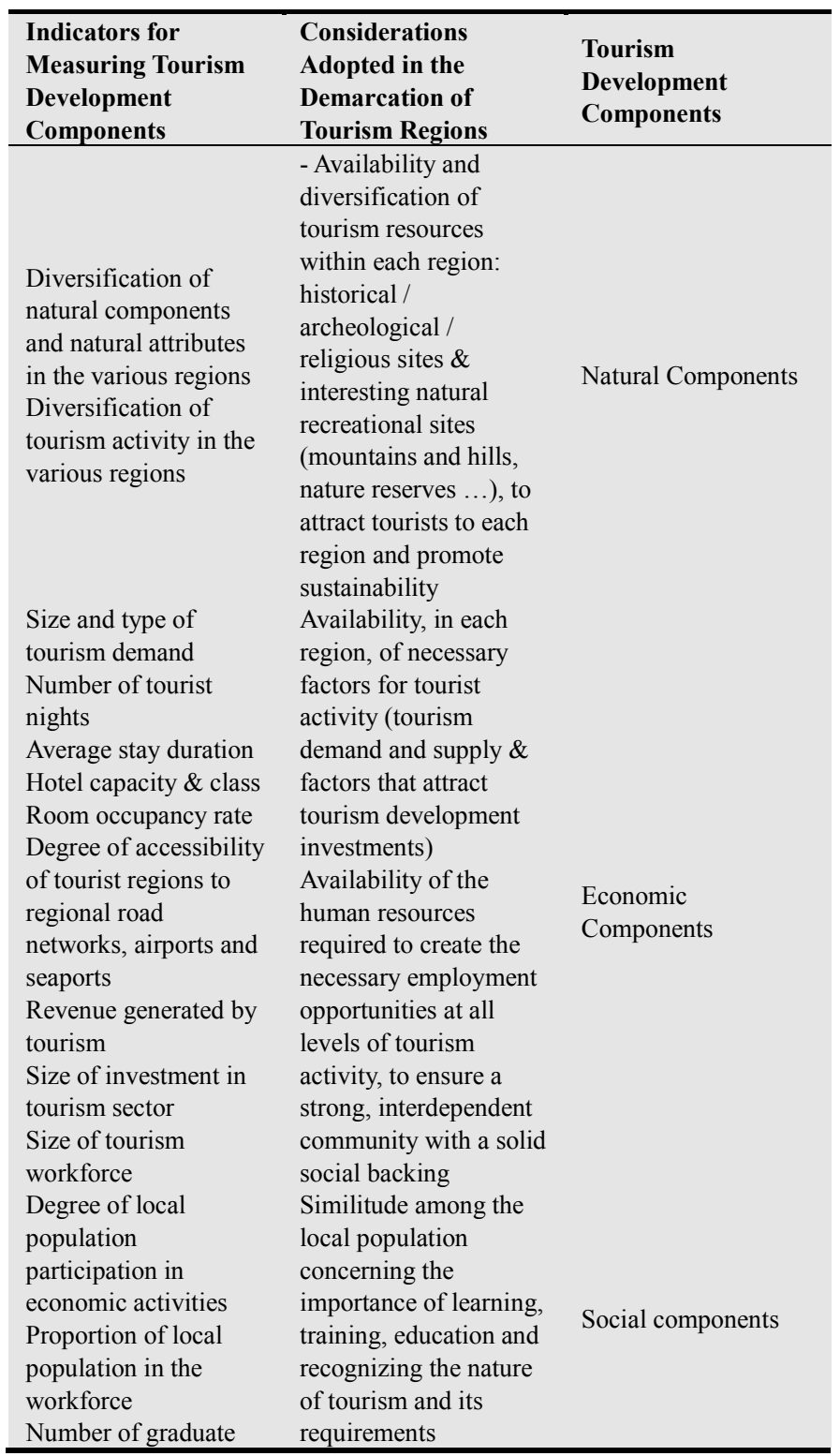

25 Egyptian Cabinet Information and Decision Support Center, Wasf misr belma3loumat, Seventh Issue, 2008 


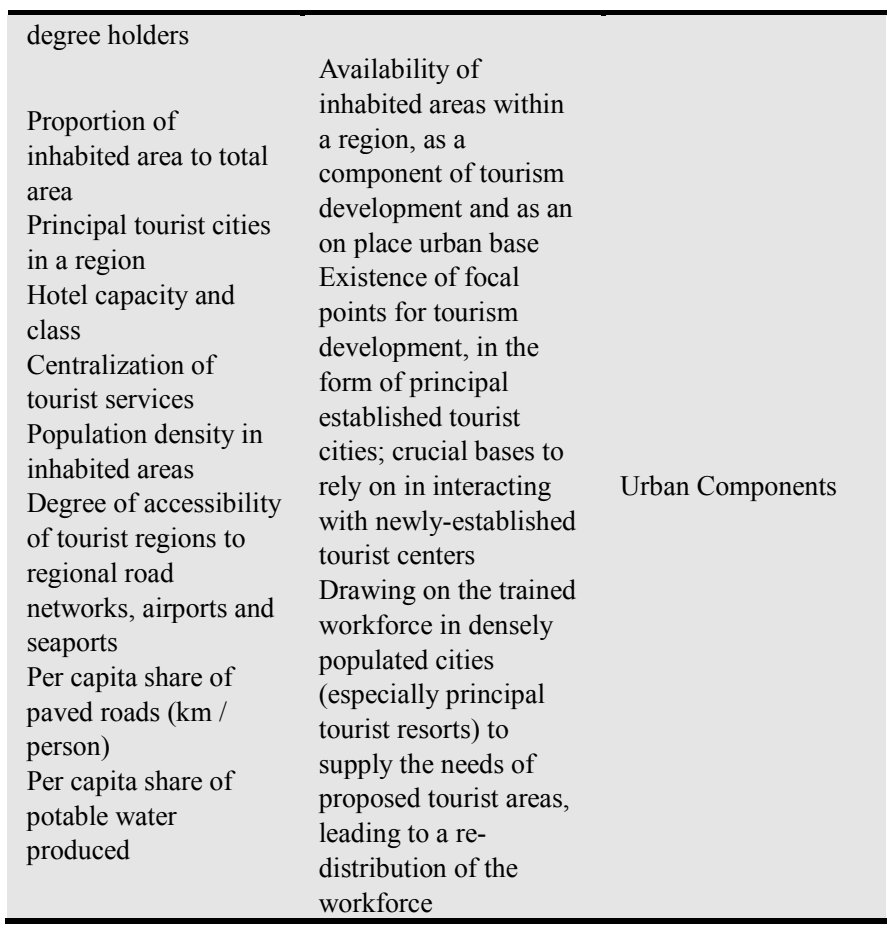

Source: Heba Mostapha Hassan Mohamed, Taqyeem dor khettat al tanmeya al seya7eya fi 3amaleyat al tanmeya al eqleemeya fi misr, Unpublished MA thesis, Faculty of Urban and Regional Planning, Cairo University, 2012

\section{Planning Regions in Egypt ${ }^{26}$}

From the regional perspective, Egypt is divided into seven planning regions, each with its own Higher Committee and Regional Planning Authority.

The seven regions are Cairo, Alexandria, the Suez Canal, the Delta, Northern Upper Egypt, Assiut and Southern Upper Egypt, distributed among governorates as follows:

1. Cairo Region: Cairo, Giza and Al Qalyubia governorates

2. Alexandria region: Alexandria, Al Beheira and Mersa Matruh governorates

3. Suez Canal Region: Northern Sinai, Southern Sinai, Port Said, Ismailia, Suez and Al Sharqiyah governorates, in addition to part of the Red Sea Governorate

4. Delta Region: Kafr Al Sheikh, Al Gharbiya, Al Menoufeyeh, Dammietta and Al Daqahliya governorates

5. Northern Upper Egypt Region: Beni Suef, Fayoum and Minya governorates as well as part of the Red Sea Governorate

6. Assiut Region: Assiut and New Valley governorates

7. Southern Upper Egypt Region: Sohag and Qena governorates, Luxor, Aswan, and part of the Red Sea Governorate

It is to be noted that, due to its linear shape, the Red Sea Governorate is divided into three planning regions. Nevertheless, it is included in the Southern Upper Egypt

26 Estrategiat al tanmeya wa al ta3meer le gomhoureyat misr al 3arabeya region in the present studies.

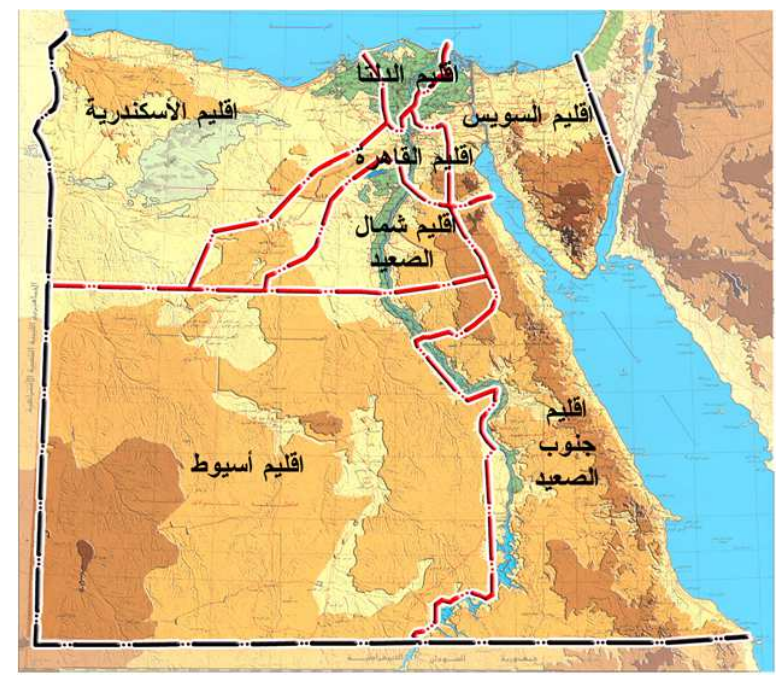

Figure 6. Planning Regions in Egypt

Source: Khareetat al tanmeya wa al ta3meer le gomhoureyat misr al 3 arabeya

There is a marked difference between the demarcation of planning and tourism regions. In the view of the Egyptian Ministry of Tourism, the main difference between the Alexandria planning region and the Alexandria tourism region is the Northwest Coast Region. Due to the unique nature and distinctive tourism constituents of the region, the Ministry of Tourism has underlined the relative national importance of the Northwest Coast Region. This study therefore focuses primarily on the Alexandria and Northwest Coast regions in order to realize a number of important objectives:

- Re-organization of urban conglomerations in the region

- Extending urbanization to the region's desert areas

- Organizing transportation facilities and linking new development plans to existing urban areas

- Using the many different tourism constituents available to provide new types of tourism and to diversify the tourism product

- Linking the Mersa Matruh tourism region to the New Valley and Delta regions through road networks and traffic axes.

\subsection{Alexandria Region}

The Alexandria Region is the second of Egypt's seven regions. In addition to Alexandria Governorate, the region includes Mersa Matruh and Al Beheira governorates (Figure 5). The total area of the region is 53330 Feddans (about 2.22\% of Egypt's total land area). According to the final 2006 census, the region's population is approximately 194.9 million (62.12\% of Egypt's population). According to the final 2006 census, there is a total of 11 coastal cities in the region, distributed as follows: two cities in $\mathrm{Al}$ Beheira Governorate, the city of Alexandria, the New Borg Al Arab city and seven cities in Mersa Matruh Governorate. 


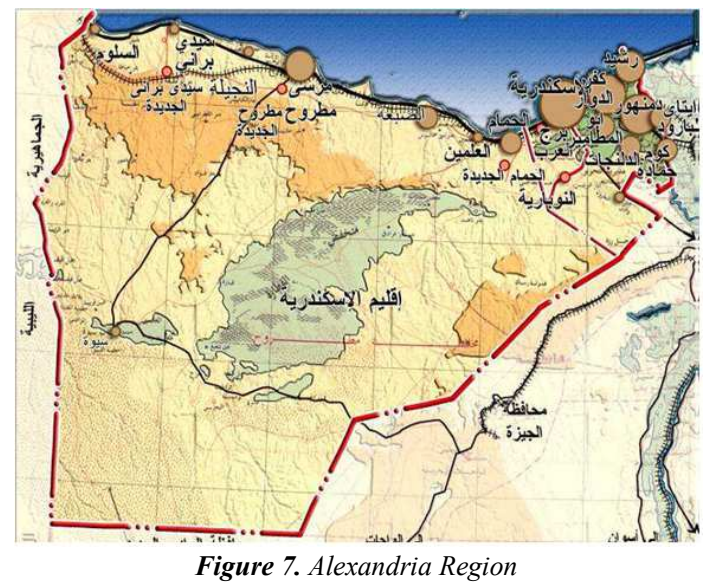

Source: Estrategiat al tanmeya le mo7afazat al gomhoreya, Iqleem al eskandereya, Chapter 3, General Authority for Urban Planning, 2008

Social Indicators:

1. With a population of 0.84 million and a population growth rate of $2.2 \%$ over the past ten years, Alexandria is the coastal city with the largest population in this region, and in Egypt generally. Mersa Matruh comes next, with a population of 8.109 thousand. Due to the rapid coastal development (tourist resorts) underway in the governorate that attracts migrant workers from neighboring governorates, the population growth rate in Mersa Matruh (7.7\% over the past ten years) is one of the highest in the region.

2. Economic Indicators:

3. The Alexandria region is rich in industrial, agricultural, fish and animal resources. The region has a huge industrial base (existing and new industrial complexes). There are a variety of industries in the region; agro industries, heavy industries, and petrochemical and construction material industries. In addition to recreational beach tourism (the most important tourism resource in the region, particularly in Alexandria and Mersa Matruh governorates), the region is rich in archeological tourism resources spread across its different governorates (Pharaonic, Greek, Roman, Coptic and Islamic antiquities).

4. Among the governorates in the region, Alexandria is the governorate with the greatest diversity of economic sectors (industrial, services and commercial sectors), which explains why the population of Alexandria City is so much larger than that of other cities in the region. In $\mathrm{Al}$ Beheira Governorate, agriculture is the leading economic activity, while Mersa Matruh is best known for the tourism services it supplies (in addition to agriculture). 27

5. The Region's Infrastructure:

6. The Alexandria Region (particularly in Alexandria and Al Beheira governorates) has an excellent land

27 Industrial Development Authority, Derassat al gadwa al awaleya le moqtara7 mamar al tanmeya bel sahara'a al gharbeya - derassa ta7leeleya le me7war aleskandereya, 2009 transportation network (road and railway) that connects the region to the nation's capital and to most capitals and major cities in neighboring governorates. The local transportation network also connects most villages and towns of the region's governorates.

7. The national and regional road network includes the international coastal highway running parallel to the country's northern coastline, from Al Salloum all the way to $\mathrm{Al} \mathrm{Arish}$. At present, this is the principal land route linking existing (or planned) tourist resorts on the Northwest Coast to other sections of the national road network.

8. The national railway network includes the Cairo - Tanta - Alexandria - Mersa Matruh - Al Salloum railway line. The railway network pattern in Alexandria and $\mathrm{Al}$ Beheira governorates is spread out, while in Mersa Matrouh Governorate it runs along a lateral line.

9. There are two seaports in the Governorate of Alexandria (the East Port and the West Port), in addition to the Mersa Matruh Commercial Seaport. Three international and national airports in the region contribute to promoting tourism development in the region: Al Nozha and Borg al Arab Airports in the Governorate of Alexandria and Al Alamein Airport in Mersa Matruh Governorate.

\subsection{Regional and Urban Studies}

The study of the regional and urban condition of coastal regions was conducted using:

1. Egyptian governorate development strategy reports issued by the General Authority for Urban Planning in 2008; a collection of comprehensive reports covering the development strategies for Egypt's governorates and the seven planning regions (Cairo, Alexandria, the Suez Canal, the Delta, Northern Upper Egypt, Assiut and Southern Upper Egypt). Each report includes a statement explaining the position and role of the region in which the governorate is located within the national spatial development system and plan. Each report also presents the framework for, and expected outputs of, the governorate's strategic development plan, according to its natural, human and urban attributes, based on official State-approved data and statistics.

2. Regional plans drafted and approved for each region:

First: Alexandria Region Development Strategies

A study of the general strategies formulated for the Alexandria Region shows that they are based on three primary principles:

- Enhancing the economic efficiency of existing activities by raising performance levels, increasing production, judicious investment and production decisions, upgrading existing infrastructure networks, and focusing on operations of replacement and renewal operations of existing assets.

- Encouraging population migration from the region's overcrowded governorates towards urban conglomerations in desert areas and new cities in the 
region

- Ensuring that new investments promote regional and national objectives by directing them toward production, services and urban sectors.

- Following the formulation of the development strategy, a number of particularly important projects were set up in the region, including:

- Tourism development of the North Coast, from Alexandria to Al Salloum (an area full of distinctive, long-term tourism development opportunities); Detailed studies have been carried out on developing of the area of the Northwest Coast sector that extends from the eastern borders of Mersa Matruh to Al Salloum by establishing service centers and integrating them into beach activities. These centers would be set up at specific points on public beaches and open areas as well as in areas with no access to public beaches. 28

- Upgrading fishing harbors and expanding fish farms and enhancing their efficiency.

Second: Northwest Coast Regional Development Plan (2007)

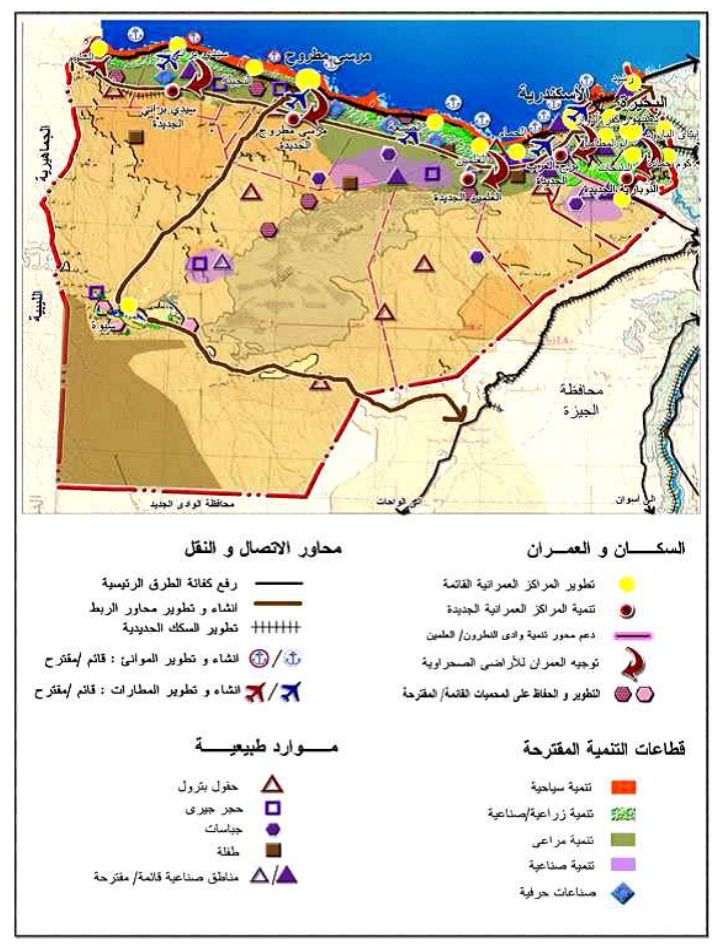

Figure 8. Alexandria Region Development Strategy

Source: Estrategiat al tanmeya le mo7afazat al gomhoreya, Iqleem al eskandereya, Chapter 3, General Authority for Urban Planning, 2008

The regional development report defines the Northwest Coast Region as the area between $29^{\circ} \mathrm{E}$ and $25^{\circ} 30^{\prime} \mathrm{W}$ longitude and $30^{\circ} \mathrm{N}, 30^{\circ} \mathrm{S}$ latitude, a $50 \mathrm{~km}$ wide area that extends along the seashore for a distance of about $500 \mathrm{~km}$. Total area of the region is approximately 20 thousand $\mathrm{km} 2(2 \%$ of the country's total area). The regional development report

28 Egyptian Cabinet Information and Decision Support Center, Wasf misr belma3loumat, Seventh Issue, 2008 thus only includes Mersa Matruh Governorate in the Northwest Coast region; the governorates of Alexandria and Al Beheira (which are part of the region) are omitted. ${ }^{29}$

Its many beaches and the desert buffer zone that extends behind the seashore from a point $61 \mathrm{~km}$ west of Alexandria all the way to Al Salloum make the Northwest Coast rich in natural potential.

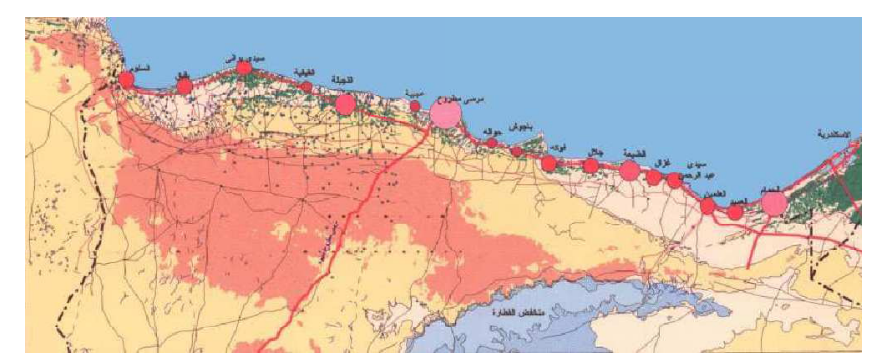

Figure 9. Northwest Coast Regional Development Plan (2007)

Source: Northwest Coast Regional Development Plan (2007), General Authority for Urban Planning, 1998

\subsection{Regional Plan Objectives}

The Northwest Coast Regional Development Plan aims at:

- Formulating a general strategy framework for realizing comprehensive development of all economic sectors and that is not limited to a single economic activity

- Judicious use of coastal urbanization to prevent random, unplanned development and its negative effect at regional and national levels (disparities between cities in Mersa Matruh Governorate and cities in other regions, and lack of equilibrium between the coastal strip - one of the region's components and the remaining components)

- The special attention accorded to the North Coast has encouraged large investment expenditures to build summer vacation units (concentrated mainly on the coastal strip) that are used only for limited periods of the year

The concept of equilibrium referred to in these objectives denotes the following:

- Developing economic and social sectors in accordance with existing demand, while stressing the presence of mutually interconnected small and largesize projects and not squandering available development resources and components

- Allocating a number of prime locations on the Northwest Coast for large projects that have the capacity to attract a high rate of economic activity and large populations

- Developing urban and other facilities necessary to support the coastal sector so as to enhance workforce and population stability. 30

29 Ministry of State for Environmental Affairs, Egyptian Environmental Affairs Agency, Al tawseef al bee'ee le mo7afazat matruh, 2008

30 General Authority for Urban Planning, Al edara al 3amma lel bo7outh wa al 


\subsection{Regional Plan Concept}

The regional plan concept was conceived to support the urban development strategy of dividing the Northwest Coast into sub-regions (planning sectors) according to the similarity of attributes, economic components and problems among the sub-regions, necessitating the adoption of appropriate urbanization policies for each region.

Accordingly, the Northwest Coast was divided into three planning sectors:

Al Hammam / Ra's Al Hekma - Ra's Al Hekma / Al Negeila - Al Negeila / Al Salloum.

We can therefore suggest three principal urban centers as administrative, economic and service sector leaders of the sub-divisions on the regional level. Naturally, the regional functions of these principal urban centers will vary according to the different resources and possibilities available to each planning sector.31

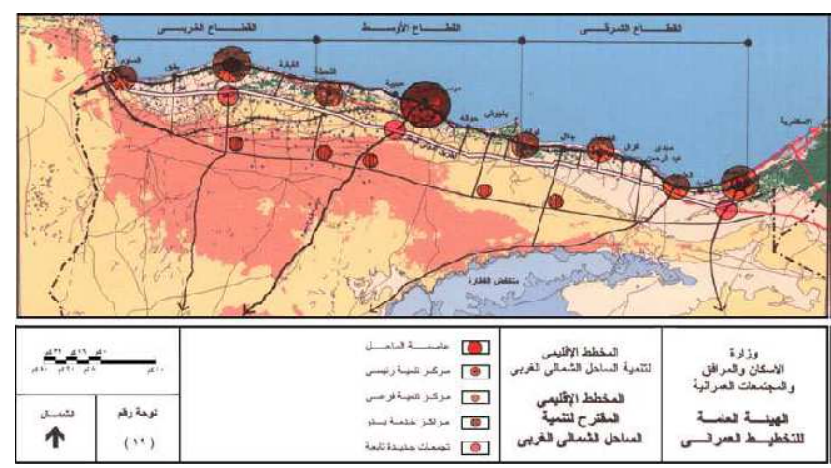

Figure 10. proposed Northwest Coast Regional Development Plan

Source: Northwest Coast Regional Development Plan (2007), General Authority for Urban Planning, 1998

Third: Development Methods Currently in Use in the Region

1. Infrastructure projects in the governorates are implemented according to the five-year plans proposed in the State budget. These cover all the kinds of infrastructure (roads, potable water, sewage, electricity and communications).

2. Law No. $119 / 2008$ (the unified building code) states that the General Administrations for Planning and Urban Development in the governorates are to draft and approve detailed city plans within a two-year period from the issuance of the law. In cases where no general plans exist (or pending the approval of general strategy plans), the General Administration for Planning and Urban Development lays down temporary rules and conditions for detailed plans regulating the urbanization process. After submission of these rules and conditions to the local People's Assembly, the governor concerned issues a decree for

derassat al bee'eya wa al tabee3eya - al derassat al bee'eya wa al tabee3eya le wa7at siwa (by Mahmoud Mohamed Nasr Allah, National Research Center),2009.

31 General Authority for Urban Planning, Ta7deeth estratejeyat al tanmeya al shamela lel sa7el alshemali algharbi wa zaheeroh al sa7rawi (2010 - 2032) their implementation pending the drafting and approval of general strategy plans.

3. Plans for the coastal cities of the region (such as Rasheed, Alexandria and New Bog Al Arab) were approved according to the above. Strategy and detailed plans for other cities have not yet been approved. $^{32}$

\section{Conclusion}

This study aimed to explain the relationship between crucial sustainable development and the development of tourism regions in Egypt. It reviews sustainable development strategy indicators for the Northwest Coast and Alexandria regions.

It discussed the Tourism Development: Objectives and Relation to Regional Development with The Principles of Sustainable Tourism "social, economic, Environment".

And also discussed the Factors Affecting the Demarcation of Tourism Regions: Natural Components, Urban Components, Economic Components, Social Components, Administrative and Political Factors, Future Dimensions of Regional Development. The paper gave a standards and Methods for Identifying Tourism Development Components, and measure the Indicators for Measuring Tourism Development Components, and finally study the north coast and west Alexandria regions in Egypt in order to sustain the tourism development in both regions.

\section{Results and Recommendations}

This study deduces that the tourism development process is a process of change during which the exploitation of resources, the directing of investments (during a given period), the thrust of technological development and institutional change all form a coherent, integrated whole, thereby increasing possibilities for linking the present to the future to provide the basic needs of tourists.

Tourism regions play a crucial part in a system where all tourist sites are integrated. A tourism region does not necessarily only refer to a geographic area. Rather, it refers to the integrated tourist facilities and services within several tourist sites that, together, form a tourism region. Bringing together all the natural and urban components within a particular geographic area facilitates integrated, comprehensive tourism development of that area. It also facilitates the use of marketing cooperatives to promote efficient marketing of the tourism region, and makes it easier to formulate integrated marketing policies for the entire region. Tourism depends essentially on effective marketing mechanisms, which are not easily realized in the context of individual, isolated sites or through small-size tourism marketing programs.

32 General Authority for Urban Planning, Estratejeyat al tanmeya lel sa7el alshemali algharbi (2022) 
This paper concludes that the major indicators of sustainable tourism development are the following:

Natural components of a region; diversification of natural components is considered one of the most important indicators of regional development

Economic components of a region; refers to a number of indicators that contribute to sustainable development of tourism regions, such as the existing demand for a region, the size of investments directed to it, and the bed capacity (hotels) available in it.

Social components of a region; refers in particular to the degree of participation of the local population in economic activities and the size of the workforce employed in the tourism sector.

Urbanization components of a region; the degree to which tourism regions are connected to regional road networks, airports and seaports, hotel capacity and class, and the centralization of tourism services are among the most important indicators of successful sustainable development of tourism regions.

Development strategy for the Alexandria Region is based on three main principles:

- Formulating a general strategy framework through which to realize comprehensive development of all economic sectors and that is not limited to a single economic activity

- Judicious coastal urbanization to avoid random, unplanned development and its negative effect at regional and national levels (disparities between cities in Mersa Matruh Governorate and cities in other regions, and lack of equilibrium between the coastal strip - one of the region's components - and the remaining components)

Because the Northwest Coast Region's positive indicators for future development stand to contribute to the growth of Egypt's gross national product, this study recommends focusing attention on tourism development, and optimizing future development plans, in this region.

The study further recommends taking full advantage of integrated development projects and applying them to the development of the North Coast, while underlining the urgent need to formulate a flexible legal framework for investment to remove obstacles facing investors in the implementation of their projects.

\section{References}

[1] Ahmed Al Galad, Al tanmeya al seya7eya al motawassela, Alam al kotob, Cairo, 2000

[2] Ahmed Fawzi, Madkhal ila 3elm al seya7a, Dar Al fekr al gamee3ee, 2008

[3] Central Agency for Public Mobilization and Statistics (CAPMAS), General Census for Population, Housing and Establishments, 2006, and 2008 Estimations
[4] Egyptian Cabinet Information and Decision Support Center, Wasf misr belma3loumat, Seventh Issue, 2008

[5] Estrategiat al tanmeya le mo7afazat al gomhoreya, Iqleem al eskandereya, Chapter 3, General Authority for Urban Planning, 2008

[6] Fahd Abdel Karim Ali Torkistani, Al seya7a al bee'eya, mafhoomha wa 3anaserha, First Edition, 2008

[7] Fatena Al Wattar, Al malame7 altakhteeteya le ta7qeeq afaaq al tanmeya al mostadama, Al mobadarat wa al "ebda3 al tanmawi fi al madeena al 3arabeya, Jordan, 2008

[8] General Authority for Tourism Development website www.tda.gov.eg

[9] General Authority for Tourism Development, Estratejeya le tanmeyat al seya7a 7atta 3am 2017

[10] General Authority for Urban Planning, Al edara al 3amma lel bo7outh wa al derassat al bee'eya wa al tabee3eya - al derassat al bee'eya wa al tabee3eya le wa7at siwa (by Mahmoud Mohamed Nasr Allah, National Research Center),2009.

[11] General Authority for Urban Planning, Al mokatat al estratigi al qawmi lel tanmeya al 3omraneya wa manateq al hay'a al 3ama lel takhteet al 3omrani - Al itar al 'eqleemi letanmeya mo7afazat eqleem al eskanderiya

[12] General Authority for Urban Planning, Estrategiat al tanmeya le mo7afazat al gomhoreya, Iqleem al eskandereya, Chapter 3, 2008

[13] General Authority for Urban Planning, Estratejeyat al tanmeya lel sa7el alshemali algharbi (2022)

[14] General Authority for Urban Planning, Ta7deeth estratejeyat al tanmeya al shamela lel sa7el alshemali algharbi wa zaheeroh al sa7rawi $(2010-2032)$

[15] General Authority for Urban Planning, Ta7deeth estratejeyat al tanmeya al shamela lel sa7el alshemali algharbi wa zaheeroh al sa7rawi (2010 - 2032), April 2011

[16] Industrial Development Authority, Derassat al gadwa al awaleya le moqtara7 mamar al tanmeya bel sahara'a al gharbeya - derassa ta7leeleya le me7war aleskandereya, 2009

[17] JICA study team, The study On Tourism Development Projects In Egypt 1F. Lawson \& Bovy: Tourism \& Recreation Development, 1979

[18] Magda Mohamed Gom3a, Goghrapheyat misr al seya7eya, 2000

[19] Majalet game3at teshreen lelderassat wa albo7outh al 3elmeya - selselat al 3oloom al'eqtessadeya wa al qanooneya, Vol. 28, Issue 3 (2006)

[20] Ministry of State for Environmental Affairs, Egyptian Environmental Affairs Agency, Al tawseef al bee'ee le mo7afazat matruh, 2008

[21] Mohamed Youssry Ibrahim De3bbes - Sena3et al seya7a bayn al nazareya wa al tatbeeq - First Edition, 2003

[22] Molakhass qera'at estratejeya al tanmeya le 'eqleem al eskandereya - mo7afazat matruh - al moqtara7aat wa al mortakezaat 
[23] Tasyeer aleyat ta7qeeq al seya7a al mostadama ma3 altatbeeq 3ala alwa7at al dakhla wa al kharga be misr, First International Symposium (Urbanism and Sustainable Tourism), Institute of Urban Management Techniques, University of M'sila, Algiers,

7 / 8 December, 2011 